BOIKO Margarita,

DSc (Economics), Professor, Head of the Department of Hotel and Restaurant Business

of Kyiv National University of Trade and Economics 19, Kyoto str., Kyiv, 02156, Ukraine

E-mail:mboyko2006@ukr.net

ORCID: http://orcid.org/0000-0003-0249-1432
BOSOVSKA Myroslava, DSc (Economics), Professor at the Department of Hotel and Restaurant Business of Kyiv National University of Trade and Economics 19, Kyoto str., Kyiv, 02156, Ukraine

E-mail:bosovskam@ukr.net ORCID: https://orcid.org/0000-0002-6021-5228

KULYK Mariia,

Ph.D. (Economics), Associate Professor at the Department of Hotel and Restaurant Business of Kyiv National University of Trade and Economics

19, Kyoto str., Kyiv, 02156, Ukraine

E-mail:kulikmariya@ukr.net

ORCID: https://orcid.org/0000-0001-8732-7441

\title{
OVERBOOKING AS THE INSTRUMENT OF REVENUE MANAGEMENT
}

The peculiarities of the use of overbooking in the hotel business have been investigated. Using the principles of overbooking which are applied in hospitality, the study found that there are statistically significant returns on the revenue in Ukrainian hotels. Prerequisites and benefits of implementing overbooking in hotel business are analyzed.

Keywords: overbooking, revenue management, hospitality, hotels, market segments.

Бойко М., Босовская М., Кулик М. Овербукинг как инструмент ревеню-менеджмента. Исследованы особенности использования овербукинга в гостиничном бизнесе. Доказана зависимость доходов украинских отелей от увеличения количества услуг перебронирования. Проанализированы предпосылки и преимущества внедрения овербукинга в гостиничном бизнесе.

Ключевые слова: овербукинг, управление доходами, сфера гостеприимства, гостиницы, маркетинговые сегменты.

Background. The development of revenue management at Ukrainian hotels requires the use of new methods that optimize overbooking levels and allocation. Modern methods for hotels are a revenue management strategy that helps to maximize the total capacity and increase the Room revenue. It is precisely the use of overbooking that can solve urgent issues of the revenue generating capabilities. Overbooking is a situation when the total number of rooms reserved for a certain period of time exceeds the total number of rooms available for sale for the same period.

(C) Boyko M., Bosovska M., Kulyk M., 2019

ISSN 1727-9313. HERALD OF KNUTE. 2019. NN 6 
Analysis of recent research and publications. The prerequisites for forming conclusions about the peculiarities of forming overbooking as a hotel revenue management optimization method in an environment where market segment prices are optimized via demand curves ahead of a planning horizon [1]. Theoretical and methodological understanding of booking cancellation patterns and enable the adjustment of a hotel's cancellation policies and overbooking tactics according to the characteristics of its bookings were analyzed in [2].

Thus, S. Ivanov, identified all possible combinations between the overbooking levels of each room type and the actual number of cancellations, no shows and early departures the hotel can face, and formulates the costs of the overbookings in each of these combinations [3]. J. Salvat, L. Zanzi, A. Garcia-Saavedra, V. Sciancalepore, X. Costa-Perez - the need to acquire slice overbooking which can provide up to $3 \mathrm{x}$ revenue gains in realistic scenarios with minimal footprint on service-level agreements [4].

G. Gallego, H. Topaloglu noted that there is no strategic investment that has a higher return than investing in good pricing instruments, one of which is overbooking [5].

V. Pimentel, A. Aizezikali, T. Baker, formulated the basic requirements and identified a simulation model of a large hotel's reservation system, validated by Marriott hotels [6].

D. Sierag, G. Koole, R. Van Der Mei, J. Van Der Rest, B. Zwart proposed a revenue management model based on Talluri and van Ryzin that takes cancellations into account in addition to customer choice behaviour $[7 ; 8]$.

In spite of the considerable amount of scientific works devoted to overbooking in the system of revenue management, it is necessary to note fragmentation and discussion of theoretical and methodical approaches concerning the use of their results in the practice of managing the subjects of the hotel business. A certain approach is an urgent task for business entities. There is no theoretical structure in the scientific literature that would justify a holistic concept of overbooking in the revenue management system. This complicates the development of organizational and economic mechanisms for its implementation and limits the possibilities of application to achieve the socio-economic goals of the functioning of business entities.

The aim of this study is to analyze the state of overbooking implementation in Ukrainian hotels, realization of hotel services segmentation by criteria of overbooking use on the basis of methods and analytical tools of data processing of web sites of Ukrainian hotels and testing of hypotheses.

Materials and methods. The research is based on the scientific works of scientists whose works reveal the managerial process of overbooking. The multidisciplinary and multidimensional nature of the scientific problem led to the application in the process of research of a set of methods: general 
science - abstraction, analysis and synthesis, inductive and deductive, historical, logical, comparison, which provided the systematic character of overbooking as a hotel revenue management optimization method.

Results. Principles of revenue management are applied in any business environment. Overbooking hotel rooms can play a big role in a hotel's revenue management strategy. The statistical and historical data should be stored and processed by the reservation manager or revenue manager to calculate optimum overbooking levels necessary for implementing overbooking methods are:

- The total number of rooms available.

- Confirmed reservations and no-shows based on historical data.

- Credit Card / Guaranteed reservations vs no-shows based on historical data.

- Expected cancellations.

- Predicted stay overs and predicted under stays.

- Predicted Walk-in guests.

- Room type wise overbooking levels.

For hotels that are just beginning to implement overbooking, it is very important in the early stages to correctly identify and shape demand segmentation, which is determined by a combination of factors such as location, list of services provided, competitive environment and price elasticity. For analysis of competitors it is possible and necessary to use widely used tools. It may be such tools as STR, to provide daily reports on the main indicators of the hotel (downloads, average price and profitability of a room) compared with the chosen pool of competitors, as well as to explore open competitor prices in electronic sales channels and various resources for information exchange between hotels.

During the high season (more than $50 \%$ occupancy in a city) all rooms in a hotel must be assigned with greater precision as well as stop sale must be announced in time to prevent overbooking which is always a bone in contention in our dealings with individual guests, corporates, business group and tour operators.

The biggest challenge in this situation - is proper working software and whole PMS (Property Management System - for example Opera). We analyzed the state of overbooking implementation in Ukrainian hotels in their high, middle and low seasons in order to fill up the property with the best (highest) rates and earn as much money as they can. But Revenue management also can consciously create overbooking. That is because in high season hotel always have no-shows (guests that have reservations and didn't show up in a hotel for a first night). For example, the hotel has a frequency of $30 \%$ of No-shows with a full occupancy, so it means there can be some overbooking for such periods in order to fill up all rooms.

In tables $1-3$ the results of research about usage the overbooking hotel rooms of different market segments at five, four and three stars hotels in Ukraine are presented. 
Overbooking of different market segments in $5 *$ hotels

\begin{tabular}{|c|c|c|c|c|}
\hline Hotel & $\begin{array}{l}\text { High } \\
\text { season }\end{array}$ & $\begin{array}{l}\text { Middle } \\
\text { season }\end{array}$ & $\begin{array}{l}\text { Low } \\
\text { season }\end{array}$ & $\begin{array}{c}\text { The level of use } \\
\text { of hotels } \\
\text { overbooking } \\
\text { tools, } \%\end{array}$ \\
\hline Hilton Kyiv & $\begin{array}{c}\text { Business Individual } \\
\text { Tactical \& Qualified } \\
\text { Offers } \\
\text { Business Groups }\end{array}$ & $\begin{array}{l}\text { Business } \\
\text { Individual }\end{array}$ & $\begin{array}{l}\text { Business } \\
\text { Individual }\end{array}$ & 55.6 \\
\hline Premier Palace & - & - & - & 0 \\
\hline $\begin{array}{l}\text { City Holiday resort \& } \\
\text { SPA }\end{array}$ & $\begin{array}{c}\text { Leisure Groups } \\
\text { Business Groups }\end{array}$ & $\begin{array}{l}\text { Leisure } \\
\text { Groups }\end{array}$ & - & 50 \\
\hline Fairmont Grand Hotel & $\begin{array}{l}\text { Business Individual } \\
\text { Business Groups }\end{array}$ & - & - & 33.3 \\
\hline Opera hotel & $\begin{array}{c}\text { Business Individual } \\
\text { Business Groups }\end{array}$ & - & - & 33.3 \\
\hline Intercontinental & $\begin{array}{c}\text { Business Individual } \\
\text { Tactical \& Qualified } \\
\text { Offers } \\
\text { Business Groups }\end{array}$ & $\begin{array}{l}\text { Business } \\
\text { Individual }\end{array}$ & - & 44.4 \\
\hline Hyatt Regency & $\begin{array}{c}\text { Business Individual } \\
\text { Tactical \& Qualified } \\
\text { Offers } \\
\text { Business Groups }\end{array}$ & - & - & 33.3 \\
\hline $\begin{array}{l}\text { Lypky Signature } \\
\text { Apartments }\end{array}$ & $\begin{array}{c}\text { Leisure Groups } \\
\text { Business Groups }\end{array}$ & $\begin{array}{l}\text { Business } \\
\text { Groups }\end{array}$ & - & 50 \\
\hline Wish family Space & - & - & - & 0 \\
\hline Leopolis Hotel (Lviv) & $\begin{array}{c}\text { Business Individual } \\
\text { Tactical \& Qualified } \\
\text { Offers } \\
\text { Business Groups }\end{array}$ & - & - & 33.3 \\
\hline $\begin{array}{l}\text { Il Decameron } \\
\text { Clubhouse (Odesa) }\end{array}$ & - & - & - & 0 \\
\hline $\begin{array}{l}\text { Kaddor Hotel Resort } \\
\text { \& SPA (Odesa) }\end{array}$ & $\begin{array}{c}\text { Leisure Groups } \\
\text { Business Groups }\end{array}$ & $\begin{array}{c}\text { Business } \\
\text { Individual }\end{array}$ & - & 50 \\
\hline $\begin{array}{l}\text { Hotel de Paris Odessa } \\
\text { MGallery by } \\
\text { Sofitel (Odesa) }\end{array}$ & - & - & - & 0 \\
\hline Nobilis Hotel (Lviv) & - & - & - & 0 \\
\hline M1 Club Hotel (Odesa) & - & - & - & 0 \\
\hline $\begin{array}{l}\text { Seasonal fluctuations in } \\
\text { the use of overbooking } \\
\text { tools, } \%\end{array}$ & 66.7 & 33.3 & 0 & - \\
\hline
\end{tabular}

Source: Own development by authors.

During research 15 Ukrainian 5 stars hotels was analyzed. Nine of them are based in Kyiv, 4 in Odesa and 2 in Lviv. We discovered that only 9 of them are using overbooking. Some of them (Hilton, Intercontinental) use overbooking affectively and fully, but the majority use overbooking tools partially or occasionally. As we can see the majority of overbooking users are based in Kyiv and only 2 hotels are based out of Kyiv - Kaddor Hotel Resort \& SPA in Odesa and Leopolis Hotel in Lviv. The main user of overbooking system is a Hilton Kyiv which uses overbooking for the market segment "Business Individual" in high, middle and low seasons. 
Table 2

Overbooking of different market segments in $4 *$ hotels

\begin{tabular}{|c|c|c|c|c|}
\hline Hotel & $\begin{array}{l}\text { High } \\
\text { season }\end{array}$ & $\begin{array}{l}\text { Middle } \\
\text { season }\end{array}$ & $\begin{array}{l}\text { Low } \\
\text { season }\end{array}$ & $\begin{array}{c}\text { The level of use } \\
\text { of hotels } \\
\text { overbooking } \\
\text { tools, } \%\end{array}$ \\
\hline Mercure Kyiv Congress & $\begin{array}{c}\text { Business Individual } \\
\text { Business Groups } \\
\text { Leisure Groups }\end{array}$ & $\begin{array}{l}\text { Business } \\
\text { Individual }\end{array}$ & $\begin{array}{l}\text { Business } \\
\text { Individual }\end{array}$ & 55.6 \\
\hline Greguar Hotel & Business Groups & $\begin{array}{l}\text { Business } \\
\text { Groups }\end{array}$ & $\begin{array}{c}\text { Business } \\
\text { Groups }\end{array}$ & 100 \\
\hline $\begin{array}{l}\text { "NATSIONALNY" } \\
\text { Hotel }\end{array}$ & Business Individual & - & - & 33.3 \\
\hline Visak & Business Individual & $\begin{array}{l}\text { Business } \\
\text { Individual }\end{array}$ & - & 66.7 \\
\hline Favor Park Hotel & - & - & - & 0 \\
\hline BonApart Hotel & Business Individual & $\begin{array}{l}\text { Business } \\
\text { Individual }\end{array}$ & - & 33.3 \\
\hline Park Inn by Radisson & $\begin{array}{c}\text { Retail } \\
\text { Business Individual } \\
\text { Tactical \& Qualified } \\
\text { Offers } \\
\text { Business Groups } \\
\text { Leisure Groups } \\
\text { Crew }\end{array}$ & $\begin{array}{l}\text { Business } \\
\text { Groups } \\
\text { Leisure } \\
\text { Groups } \\
\text { Crew }\end{array}$ & Crew & 53.3 \\
\hline Aloft Kyiv & $\begin{array}{c}\text { Business Groups } \\
\text { Leisure Groups } \\
\text { Crew } \\
\end{array}$ & $\begin{array}{c}\text { Business } \\
\text { Groups } \\
\text { Crew } \\
\end{array}$ & - & 55.5 \\
\hline $\begin{array}{l}\text { Boutique Hotel } \\
\text { Vozdvyzhenskiy }\end{array}$ & Business Individual & $\begin{array}{l}\text { Business } \\
\text { Individual }\end{array}$ & $\begin{array}{l}\text { Business } \\
\text { Individual }\end{array}$ & 100 \\
\hline $\begin{array}{l}\text { Axelhof boutique hotel } \\
\text { (Dnepr) }\end{array}$ & - & - & - & 0 \\
\hline Viva Hotel (Kharkiv) & Business Groups & - & - & 33.3 \\
\hline City club Hotel (Kharkiv) & Business Individual & - & - & 33.3 \\
\hline LH Hotel\&Spa (Lviv) & Business Individual & - & - & 33.3 \\
\hline $\begin{array}{l}\text { Intourist hotel } \\
\text { (Zaporizhya) }\end{array}$ & - & - & - & 0 \\
\hline Marlin Hotel (Odesa) & - & - & - & 0 \\
\hline $\begin{array}{l}\text { Seasonal fluctuations in } \\
\text { the use of overbooking } \\
\text { tools, } \%\end{array}$ & 73.3 & 46.6 & 26.6 & - \\
\hline
\end{tabular}

Source: Own development by authors.

Almost all 4* hotels in Kyiv use overbooking unlike using this instrument in hotels in other Ukrainian cities isn't so frequent. The most standard situation is overbooking in high and middle seasons. Also we often can encounter overbooking for the market segment "Business Individual" and "Crew". The main user of overbooking system among $4^{*}$ hotels in Ukraine is "Park Inn by Radisson" which uses overbooking for the market segment "Crew" in high, middle and low seasons. 
For analysis hotels price changing we have chosen thirteen $3 *$ hotels: 10 in Kiev and 3 in Cherkassy. As a result we can see that at least 8 hotels use overbooking system but only in Kyiv.

Table 3

Overbooking of different market segments in $3 *$ hotels

\begin{tabular}{|c|c|c|c|c|}
\hline Hotel & $\begin{array}{l}\text { High } \\
\text { season }\end{array}$ & $\begin{array}{l}\text { Middle } \\
\text { season }\end{array}$ & $\begin{array}{l}\text { Low } \\
\text { season }\end{array}$ & $\begin{array}{l}\text { The level of use } \\
\text { of hotels } \\
\text { overbooking } \\
\text { tools, \% }\end{array}$ \\
\hline Golden Gate Inn & $\begin{array}{c}\text { Business Individual } \\
\text { Tactical \& Qualified } \\
\text { Offers } \\
\text { Business Groups }\end{array}$ & $\begin{array}{l}\text { Business } \\
\text { Individual }\end{array}$ & - & 44.4 \\
\hline Verhovyna Hotel & - & - & - & 0 \\
\hline Ukraine Hotel Kiev & Business Individual & $\begin{array}{c}\text { Business } \\
\text { Individual }\end{array}$ & - & 33.3 \\
\hline Hotel Complex Tourist & Business Groups & - & - & \\
\hline Salut & - & - & - & 0 \\
\hline Premier Hotel Rus & $\begin{array}{c}\text { Tactical \& Qualified } \\
\text { Offers } \\
\text { Business Groups } \\
\end{array}$ & - & - & 33.3 \\
\hline Hotel Druzhba & $\begin{array}{c}\text { Business Individual } \\
\text { Tactical \& Qualified } \\
\text { Offers } \\
\text { Business Groups }\end{array}$ & $\begin{array}{l}\text { Business } \\
\text { Individual }\end{array}$ & - & 44.9 \\
\hline Mir Hotel & Business Groups & - & - & 33.3 \\
\hline Premier Hotel Lybid & $\begin{array}{c}\text { Tactical \& Qualified } \\
\text { Offers } \\
\text { Business Groups } \\
\end{array}$ & - & - & 33.3 \\
\hline Ibis Kiev City Center & - & - & - & 0 \\
\hline Knyazha Hora Hotel & - & - & - & 0 \\
\hline $\begin{array}{l}\text { Optima Cherkassy } \\
\text { Hotel }\end{array}$ & - & - & - & 0 \\
\hline $\begin{array}{l}\text { Ukraina Hotel } \\
\text { Cherkassy }\end{array}$ & - & - & - & 0 \\
\hline $\begin{array}{l}\text { Seasonal fluctuations in } \\
\text { the use of overbooking } \\
\text { tools, } \%\end{array}$ & 57.1 & 21.4 & 0 & - \\
\hline
\end{tabular}

Analysis of the overbooking process for different segments of the market showed that the main problem faced by hotels when using overbooking is that, despite the set of booking applications exceeding the total number of rooms, there is downtime in the number of rooms in the intervals between bookings (figure) [9].

An analysis of the overbooking process for different market segments showed that the main problem that hotels encounter when using overbooking is that, despite a set of requests for the number of rooms exceeding the total number of rooms, downtimes are formed in the intervals between reservations. 


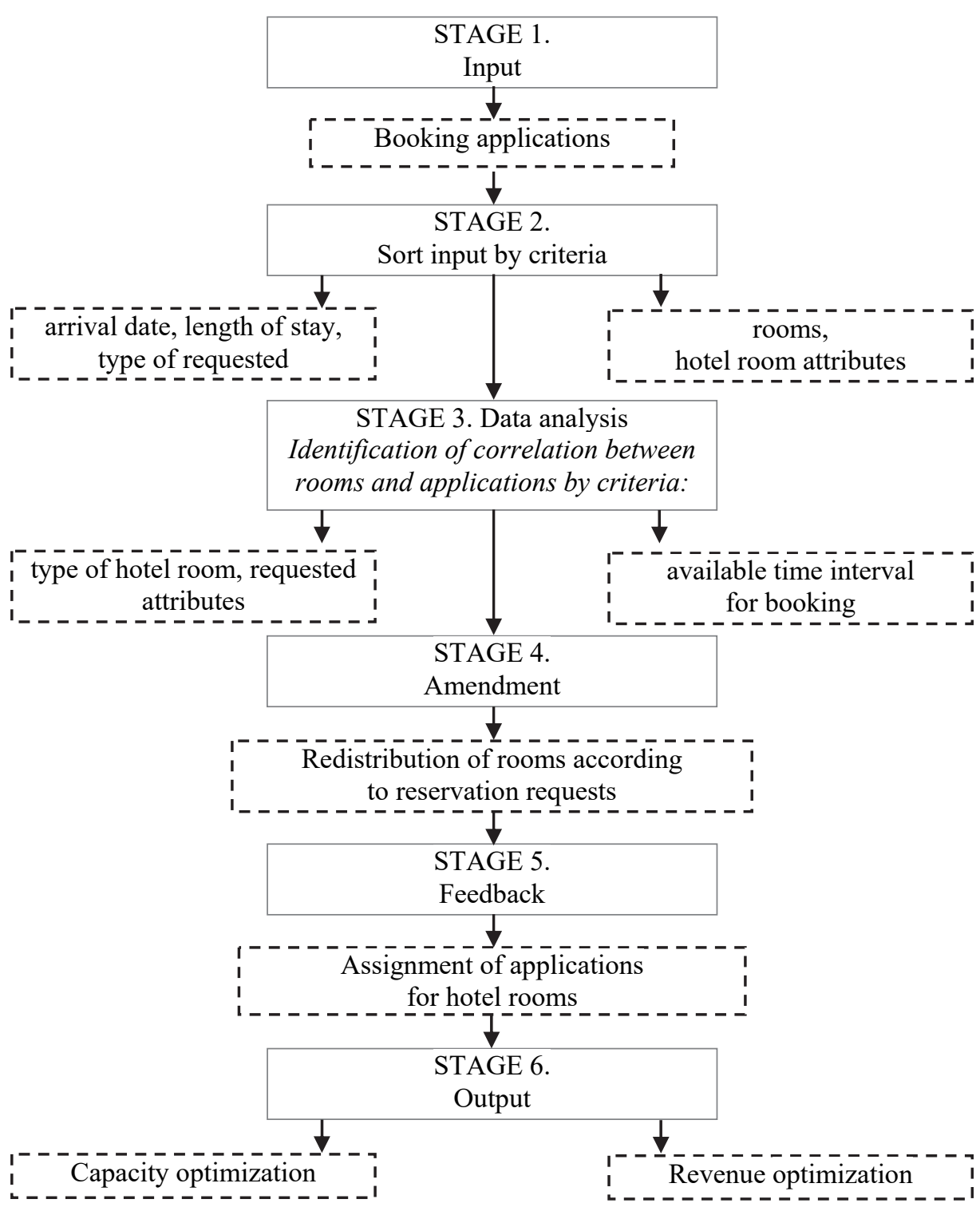

The interdependence of overbooking and revenue management system optimization of hotel revenues

Source: developed by authors based [9].

The methods of Revenue Management are increasingly interested in the owners and managers of hotels, including the small numbered stock, but still not all managed to implement a profit management system. The market in this direction is only developing. The profitability management - both from the sale of rooms and for the provision of additional services, banquet and conference rooms, and events - will be the main trend of the hospitality industry for many years. The revenue manager can, on the one hand, optimize profitability and profitability not only from sales of rooms but also 
other profit centers of the hotel; on the other hand, knowing (analyzing) the habits of regular guests, you can increase their loyalty by offering a personalized approach to providing special conditions for services the hotel. The hotel will have $100 \%$ occupancy only if all rooms will be actually occupied by guests by the end of the day. That is why hotels with such high occupancy demand all reservations to be paid in advance or they will be cancelled on the day of arrival.

If the hotel is overbooked and all guests come on time to check-in and there are no rooms left to offer, this hotel needs to find hotel with same level and that has available room with same room category and organize the transfer for guest(s). What is the most important that the rate per room has to be the same that guest(s) has in his reservation.

For example, Radisson Blu Kyiv Hotel has an agreement with 3 hotels in Kyiv: Radisson Blu Podil, Park Inn and Holiday Inn for allowing accommodation for their guests in case of overbooking. These hotels are located in city center and close to each other.

Usually overbooking happens in a $3^{*}$ and low $4^{*}$ hotels - Ramada, Mercure, Park Inn. The highest occupancy level in Kyiv was during UEFA Championship League Final when all $4^{*}$ and $5^{*}$ hotels were full booked at the time of announcing such event in Kyiv. Hotels set high rates from the very beginning. The problem was that not all guests come to the hotel on the day of arrival (no-show) and that gave the hotel chance to sell those rooms even for higher rate than it was. That is why period of 24-26 May was the most profitable period for hotels (around $20 \%$ of annual revenue was earned in those few days - accommodation + meetings $\&$ events + food $\&$ beverage parts). For night from 25.05 to 26.05 rate per single standard room was 1200 euro in Park Inn (only 1 room was available), 500 euro in Holiday Inn (2 rooms available) and 900 euro in Alfavito (1 room available).

Hotels that meet all of the above conditions will be able to show better results with revenue management methods. The size and style of the hotel, as well as the market where the hotel operates, will affect the observance of each of these conditions. For example, your market may be limited geographically, or you have to set prices in accordance with the instructions of the government. However, your product will most likely meet at least two of the three requirements outlined above.

To date, in Ukraine there is an obvious tendency to develop this technology not only in network and large hotels, but also in small hotels, where only one employee can handle income control.

Conclusion. The system of overbooking allows us to evaluate all aspects of the business activity of the subject of the hotel business, concerning the target segments and other weighty components. Summarizing the results of the study overbooking as an effective instrument of revenue management in hospitality, it can be stated that in order to achieving economic activity goals. It is important for the business entities to apply management technologies 
that promote the introduction of information innovation and consolidation of intellectual resources. These instruments are the basis for regulating the successful management of hotel business entities, creating the necessary conditions for efficient use of resource potential and service quality. The implementation of overbooking in the hotel business management system will enable the hotel companies not only to increase competitiveness in the market, but also to increase capitalization, increase investment attractiveness. Hotel management must be able to use an effective market monitoring system that combines management (operational and strategic levels), information, marketing, accounting components.

This will allow to determine the volumes of application of overbooking at different time periods in order to ensure the optimal structure of hotel services, to identify potential reserves of demand satisfaction, to differentiate target segments of hotel services customers.

Accordingly, in further studies, it is advisable to focus scientific discussions on the use of overbooking in the plane of constructing theoretical and applied models that reveal the essence of its implementation through the prism of certain hotel services customers segments differentiation.

\section{REFERENCES}

1. Pimentel, V., Aizezikali, A., \& Baker, T. (2019). Hotel revenue management: Benefits of simultaneous overbooking and allocation problem formulation in price optimization. Computers and Industrial Engineering, 137 [in English].

2. Antonio, N., de Almeida, A., \& Nunes, L. (2019). Big Data in Hotel Revenue Management: Exploring Cancellation Drivers to Gain Insights Into Booking Cancellation Behavior. Cornell Hospitality Quarterly, 60 (4), (pp. 298-319) [in English].

3. Ivanov, S. H. (2015). Optimal overbooking limits for a hotel with three room types and with upgrade and downgrade constraints Tourism Economics, 21 (1), (pp. 223-240) [in English].

4. Salvat, J. X., Zanzi, L., Garcia-Saavedra, A., Sciancalepore, V., \& Costa-Perez, X. (2018). Overbooking network slices through yield-driven end-to-end orchestration. CoNEXT 2018 - Proceedings of the 14th International Conference on Emerging Networking EXperiments and Technologies, (pp. 353-365) [in English].

5. Gallego, G., \& Topaloglu, H. (2019). Overbooking. International Series in Operations Research and Management Science, 279, (pp. 83-105) [in English].

6. Pimentel, V., Aizezikali, A., \& Baker, T. (2018). An evaluation of the bid price and nested network revenue management allocation methods. Computers and Industrial Engineering, 115, (pp. 100-108) [in English].

7. Sierag, D. D., Koole, G. M., Van Der Mei, R. D., Van Der Rest, J. I., \& Zwart, B. (2015). Revenue management under customer choice behaviour with cancellations and overbooking. European Journal of Operational Research, 246 (1), 170-185 [in English]. 
8. Kalyan, T., Talluri, \& Garrett J. van Ryzin (2004). Revenue Management Under a General Discrete Choice Model of Consumer Behavior Published in Management Science [in English].

9.Kostin, K. B. (2016). Innovacionnyj podhod k resheniju problemy overbukinga kak odnogo iz kljuchevyh aspektov jeffektivnoj marketingovoj politiki otechestvennyh i mezhdunarodnyh predprijatij turistskogo biznesa [An innovative approach to solving the problem of overbooking as one of the key aspects of an effective marketing policy of domestic and international tourism enterprises]. Izvestija Sankt-Peterburgskogo gosudarstvennogo jekonomicheskogo universiteta - News of St. Petersburg State University of Economics, 1 [in English].

The article submitted to editor's office on 15.11.2019.

\begin{abstract}
Бойко М., Босовська М., Кулик М. Овербукінг як інструмент ревенюменеджменту.

Постановка проблеми. Впровадження системи ревеню-менеджменту в украйнських готелях вимагає застосування нових методів, щзо оптимізують рівень завантаженості та розподілу номерного фонду. Сучасний метод управління доходами в готельному бізнесі - це стратегія овербукінгу як ефективного інструменту ревеню-менеджменту. Саме використання овербукінгу може вирішити актуальні питання пошуку резервів отримання доходу. Овербукінг - ситуація, коли загальна кількість номерів, зарезервованих за певний проміжок часу, перевищує загальну кількість наявних у продажу номерів за той же період.

Метою статті є аналіз стану застосування овербукінгу в готелях Украӥни, здійснення сегментації готельних послуг за критерієм використання овербукінгу на основі методів та аналітичних інструментів обробки даних вебсайтів готелів України, перевірка гіпотез.
\end{abstract}

Матеріали та методи. У роботі використано такі загальнонаукові методи, як синтез, аналіз, порівняння, абстракція та індукція.

Результати дослідження. Проаналізовано стан використання овербукінгу в украӥнських готелях на основі методологї ревеню-менеджменту у високий, середній та низький сезони. Визначено рівень використання овербукінгу за основними ринковими сегментами в готелях $3^{*}, 4^{*}$ ma 5*. На основі даних STR-звітів виявлено основні тренди сегментації готельних послуг за критерісм використання овербукінгу.

Висновки. Система овербукінгу дає змогу оцінити всі аспекти ділової активності суб'єкта готельного бізнесу щзодо иільових сегментів та інших вагомих складових. Для суб'єктів господарювання важливо застосовувати технології управління, які сприяють впровадженню інформаційних інновацій та консолідації інтелектуальних ресурсів. Ці інструменти є основою для регулювання успішного управління суб'єктами готельного господарства, створення необхідних умов для ефективного використання ресурсного потенціалу та якості обслуговування. Впровадження овербукінгу в системі управління готельним бізнесом дасть змогу готельним операторам не тільки підвищити конкурентоспроможність на ринку, але й збільшити капіталізацію та інвестиційну привабливість. Менеджмент готелів повинен бути в змозі використовувати ефективну систему моніторингу ринку, щзо поєднує управління (операційний та стратегічний рівні), інформацію, маркетинг, бухгалтерські компоненти.

Ключові слова: овербукінг, управління доходами, сфера гостинності, готелі, маркетингові сегменти. 